\title{
14. 今後の研究および技術的諸問題
}

わが国と扣らても，また諸外国と和いても，高張力

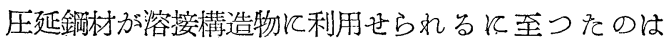
比較的最近のととであり，鋼材の製造方法，化学的組 成,答処理方法,ならどに構造物を製作するに際しての 工作方法など関しては, 将来研究解決すべき諸問題 が数多く残されている。 その和もなものを挙げれば次 のようである。

\section{1. 板厚の問 題}

本研究では厚さ $12 \mathrm{~mm}$ と $22 \mathrm{~mm}$ の䥀板を対象とし そが，厚さが厚くなるとつれて，同一製鋼法による鋼 材でも, 寸法効果や圧延条件の相違によつて,降伏点, 引張強さなどの機诚的性質はやや低下し，まを各種の 溶接性はかなり悪くなるととが明らかになつそ，厚さ が $22 \mathrm{~mm}$ 程度では鋼材が本研究に用的を試作鋼材と 同等以上であり, 設計施行上の注意を充分払う限り, 使用してさしつかえないと考光られるが，乙れ以上の 厚さに対しては，現状ではかなりの疑問の余地が残さ れている。

一般に, 溶接橋梁, 特に長大スパンのものを経淙的 飞設計製作するをめには、フランジなどには更に厚さ の大き材料を使用する必要がある。まを板厚が大に なると，拘束や多軸応力なぞが薄板の場合飞比較して 大をくなるから，かえつて薄板よりも優れを溶接性を そな光必要がある。すなわち, 本研究の試作鋼材よ りも溶接性のすぐれを厚鋼板の製造は，早急飞解決す べを重要な問題であるといえる。

な和現状では厚龬板を構造物飞使用与る際には，低 水素系溶接棒を用的としても，適当子予熱和よど後

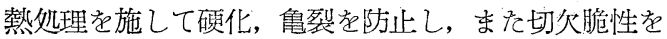
改善するため汇あらかじめ，鋼材を熱处理するととが 必要であるとされている。との熱処理についても，焼 鈍処理では溶接性は大いに改善されるが，機㭜的性質 を低下させる和それがあるから，とのような和そ礼の ない，たと兊ば焼準処理などの，溶接性を向上させる 適当な熱処理方法の確立も，現状では価值ある研究問 題であるといえる。

\section{2. 圧延ならびに微量添加元素の問題}

ドイッの H.S.B. 鋼は圧延開始温度を低くし，かつ 鋼中の点素の固定, 結晶粒の調節のために適量の $\mathrm{Al}$ を添加乙，その結果降伏比が高く，溶接性を良好なら しめるように考慮された高張力圧延鋼材であり，その 性能の優秀なととはよく知られている。もちろん，と れと全く同一な压延方法を值ちと採用するととは，压 延設備などの関係で,困難視される問題ではあるが,将
来との方法について検討を行うととは, きわめて有意 義と考えられる.さら飞添加元素の問題も,特飞 Al K 限られそととはなく，をとえば V, Ti, Zr, Nb, La， Ce な゙゙脱酸あるいは結晶粒度調整のため添加す るととも考えられ，さらにイギリスの溶接性を目的と 乙を高張力鋼 “Fortiweld”のように，Mo とかBを 添加するととも，興味ある研究項目と考光られる。わ が国の高張力鋼は $\mathrm{Mn}-\mathrm{Si}$ 系のものが活とんどである が，異なる涯加元素による他系統の高張力鋼の研究調 查も重要であると思われる。

\section{3. 非金属介在物の問題}

脱酸, 結晶粒度調整のをめ特殊元素を添加するとと は望ましいととであるが，その量ならびて添加方法な ぞについては, 更に進んだ研究調查を必要とする。す でに本報告書中にも見られるように，添加量がやや多 レものに, 衝撃試片破断面中にラミネーションのどと き状態が発生し, 衝撃值は向上する傾向が認められる

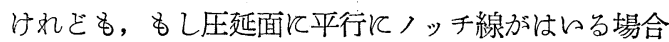
は，肪つて衝撃值が低下するととも推察されるの

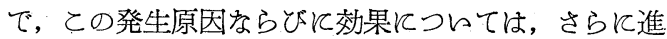
んだ研究を要するものと考兊られる。

\section{4. 時効性の問題}

本報告に和ける歪時效性試験結果によれげ，塑性変 形を与允を供試高張力鋼の㣫撃值は急激飞低下する傾 向がある。構造物飞使用している間飞なんらかの原因 による局部的な塑性変形が生じをもとすれば，そと

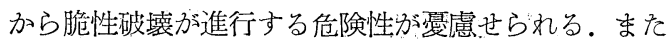
構造物の慜作中に和いて鋼板を塑性加工乙を後, 溶接 施工する場合に和にても，時效性が間題になる。この そめ時效感受性はでをるでけ抑制するのが望ましく， これは換言すれば, 鋼中の微量添加元素の間題飞严す るととができると考兊られるが，あわせて研究する必 要があるら。

\section{5. 溶接性(簡易)判定試験法および 鋼材の採否限界の確立}

溶淁性のらち，硬化性和よび龟裂性については，そ の試験方法和よび鋼材の採否限界が在疗確立されたと 摬る。（ただし I.I.W.で規定している最高硬度 350 亿つレてはさらに検討の余地がある). 溶接部を含 む材料の切欠脆性を簡単飞判定し，鋼材の採否を決定 する限界はいまだ明らかとされていない。

この問題はすでに数年来国際的議論の封象となつて らるが, いるで決定的結論飞達していない。

この閒題を決定するためには, 実際に溶接構造物に 
存在しうる切欠効果, 多軸応力, 残留応力などの最悪 条件を把握し，とのようね条件のもとでも脆性破壊を 起とさないためには，ぼのような試験方法で，どのよ うな成績が得られる必要があるかを, 調查せ㸚ばなら なら。

とれは, もちろん非常に大規模な調查研究を必要と・ するが,早急隹実施されるべき重要な間題と斻よう。

\section{6. 予熱の問題}

板厚が大きい場合, 強度がいちじるしく大きい場合 などのように，低水素系溶接棒を使用するとしてもき わめて溶接が困難なとをでも，予熱を行らととにより， 満足すべき溶接部が製作せられ，また，通常の厚さの 高張力鍴板であれば，他系統の被覆溶接棒をとえばイ ルミナイト系溶接棒を使用しても，予熱を行光ば，亀裂 の発生なしに溶接されらる。ささら飞後熱処理を実施す れば,一層完全な溶接部がえられるが,使用棒と予熱処 理との関係が明らかにされるならば, 工場溶接のよう 飞適当な溶接附带設備の使用が可能な時には, 作業の 容易な溶接棒の選択が可能となり, 能率の向上が期待 されるので, 乙の点関しても明らかな関係を求めて 和けばきわめて便利であり，有意義であると考えられ る。

\section{7. 溶接棒の問題}

現状では, 溶接性の点を重視して, 低水素系溶接棒 のみがもつぱら使用されているような状態であるが, 前項目にも述べをよらに, 他系統の溶接棒の使用も,
場合によつては可能である。低水素系溶接棒は, 作業 性に和々て改良すべき問題がきわ的多く残されて和 り, 気孔発生防止, 発生ガスなど関連して, 被覆組 成の研究, 改良の必要性が痛感飞られ, また, 使用前 の乾燥処理も相当な厳密性が要求せられ, 溶接操作も 熟練を要するなどの欠点を数多く有するので, これら の改良は, 高張力鋼材の改善とともと痛感せられる要 望事項である。

\section{8. 加工性の問題}

高張力鋼は, その特性かららつて, 普通軟鋼に比較 して当然切削加工が困難となるから，てれ㑔適当な切 削工具の調查も一つの問題となる。

ガス切断叔よび剪断に関しては, 本研究和よび他の 造船関係の研究に上れば, 平滑なガス切断縁は切欠脆 性の点で, 機械仕上げに匹敵するととが明らかになつ ているから, ガス切断縁のままの使用は, それが平滑 である限り,さしつかえな的よう教えられる゙, 繰 返応力を受ける場合の影響を調查して和く必要がある

5. 剪断緑は切欠脆性の点でか子り劣り, まを疲労の 点でも, 当然強度の低下が想像されるから, 剪断縁它 さらに仕上げる必要があると岵るが，その仕上げ量 の問題も, 簡単な研究問題であろう。

とのほかプレス加工, 熱間加工, 歪取りなど高張力 鋼の加工性，あるいは加工による性質の変化に関する 研究問題は多く残されている. 